\title{
Iconic Character of Bestiary Images in the Novels of F. Werfel and E. Canetti
}

\author{
Seibel Nataliya E, ' Shastina Elena $\mathrm{M}^{\mathbf{*}^{*}}$ Kazakova Julia K,'̀ and Ziganshina Nailya $\mathrm{F}^{\hat{\imath}}$
}

\section{Abstract}

The anthropomorphic depiction of animals bearing allegorical meanings is the well-represented and actively demanded bestiary of world literature. It reflects the mythological thinking of writers and is an integral part of the worldview basis on which literary works are based. Bestiary images in the artistic text acquire the status of universal representative symbols. This study discusses bestiary images in novelistic works of Austrian writers, Franz Werfel (1890-1945) and Elias Canetti (19051994). Using the semiotic approach, the researchers define a range of images and meanings that are related to these two writers as representatives of the era of historical upheavals and individual authorial purposes that reflect the basis of the worldview of each of them. A bestiary image in a literary text can function as an iconic sign, which, on the one hand, reflects the material object in its materiality, and on the other hand, contributes to the emerging of "new", constructed by analogy, aesthetic reality. The similarity to the referent, in this case, is included in the overall system of ontological values. An iconic sign, after Ch.S. Pierce, refers to a simple sign based on the similarity to a thing and participating in the creation of symptoms of a higher order - symbols. Bestiary images in a literary text acquire the status of universal representative characters. The functioning of animal images in the text, their nomination, combinatorics, communication with the elements, time periods, and behavioural patterns are the way of the study of the philosophical foundations of the author's world picture. Canetti's bestiary is represented by metaphorical images of a monkey, a cat, a pig, and a tortoise, which are used as a tool for analysing various psychic and psychological states of the characters of the novel "Blinding" (Die Blendung, 1931-1932). Multiple forms of anthropopathy and zoomorphism are based on the writer's attitude towards the initial "equality" of man and animal. The study of zoopoetics (the term of J. Lacan) of Werfel's novel "Barbara, or Piety" (Barbara oder die Frömigkeit, 1929) helps to reveal the axiological foundation upon which the writer constructs his novels. The functioning of images of animals, a horse, for example, is related to the semantics of sacrifice that is rethought and acquiring new meanings in a new historical context. Composite images connecting different characteristics and associated with various natural elements are important. It is apparent that the study of the works by Werfel and Canetti, given the iconic nature of bestiary images, seems relevant to detect common patterns of development of European literature and culture of the first third of the 20th Century.

Keywords: Animal Poetics; Archetypical Consciousness; Bestiary Images; Iconic Sign; Symbol

\footnotetext{
${ }^{\dagger}$ Doctor of Sciences (Philology), Professor, Department of Literature and Methods of Teaching Literature, South Ural State Humanitarian Pedagogical University, Chelyabinsk, Russian Federation

${ }^{*}$ Corresponding Author, Email: shastina@rambler.ru

¥ Doctor of Sciences (Philology), Professor, German Philology Department, Kazan Federal University, Yelabuga, Russian Federation

' Associate Professor, English Philology and Cross Cultural Communications Department, Kazan Federal University, Yelabuga, Russian Federation

î Associate Professor at the Department of Foreign languages and translation studies, Kazan Innovative University named after V. G. Timiryasov, Kazan, Russian Federation

(C) 2020 Seibel et al. This is an Open Access article distributed under the terms of the Creative Commons Attribution License (http://creativecommons.org/licenses/by/2.0), which permits unrestricted use, distribution, and reproduction in any medium, provided the original work is properly cited.
} 


\section{Introduction}

The combination of the anthropomorphic and the zoomorphic is a permanent way of creating bizarre, but emotionally and communicatively filled images in literature. A priori, "animal" is one of the "basic ontological categories, since it allows involving the most varied and detailed modes of metaphorization" (Mikhaylin \& Reshetnikova, 2013: 322). J. Derrida wrote in "Grammatology" that "from the ancient animal fable to a change in the relationship between man and the beast of the times of Louis XIV and Descartes ... an animal is used to interpret man, but without limitation or fear" (Derrida, 2000, 189), associated with respect for human nature. Attempts to systematise bestiary images began in the history of art rather early and always led to interesting and significant observations. A classic work by C. de Plancy "Infernal Dictionary" that was published in France at the beginning of the 19th Century and has been republished a huge number of times may be used as an example.

In fact, we are talking about literary animalier art or animalistic literature - both terms are used when talking about the reflection in the artistic world of the author of the image of the animal in all its diversity. The role of animal characteristics in the text is diverse; they can be a "projection of social attribution" (Bartelmus,2015, 161) and a way of studying social behaviour, since, according to Deleuze and Guattari, "every animal is mainly a gang, a pack" (Deleuze and Guattari, 2007, 8). They "perform a symbolic, allegorical or satirical function" (Driscoll, 2015, 212), becoming "mediators of metaphorical interpretation", or embody "Becoming-Animal" (an animal in its development: a reflection of the psychological evolution of a character moving from human to non-human) (Bartelmus, 2015, 162).

In modern studies, there has been growing interest in so-called "anthropological animalism" ("human-animal studies"), which includes various approaches to understanding the relationship between man and animal. The two most important concepts in this study are related, firstly, to the animal as a sign, embodying the author's philosophy, "specific, used to express the abstract" (Norris, 1985, 17), where man is a starting point for building the artistic world and animalism is interpreted semiotically, secondly, to the animal as a new "point of reference" for narration, the embodiment of the "inhuman world view" (Driscoll, 2015, 214), the experience of "what can be experienced only without words" (Driscoll, 2015, 216). In this case, the animal is associated with the "problem of writing", embodies the change of the narratological position. The first idea is based on the principle of cosmogonic unity, concentrated on the human world view and submission of animalistic images to it in the humanistic Cartesian tradition. The second one is based on man's awareness of his own animal nature, the crisis of language ("Sprachkrise"), and the rejection of positivism. The animal becomes a new point of reference, a new focus.

Kari Drikoll connects the emergence of the animal narratological concept with the basic work of an Austrian literary scholar Oscar Walzel "New Animal Poetry" (Oskar Walzel's "Neue Dichtung vom Tiere", 1918), where Rilke, Kafka, Werfel, and others were called new animalist poets. He supposes that the change of perspective re-actualises the issue of the nature of a metaphor and the essence of an artistic image.

This study analyses the texts of the authors, whose animalistic layer of creativity is as wide as possible (Bozhkova et al., 2019; Saenko et al., 2019; Magsumov, 2019). Werfel and Canetti repeatedly experiment both with the narrative position and with the cultural-historical contexts, in which bestiary images take on special significance.

Animalism by Werfel and Canetti is considered, firstly, as a reflection of the detached position of the character who is an observer in both novels, but not a participant in historical and cultural shifts of the revolutionary era; secondly, in 
connection with the idea of charity and the relationship of human life with cultural values and history movement (Addai-Mununkum, 2019; Vural, 2019). The study begins with a brief description of the methods entailed in this research. Following this, we outline the results of the study. In the discussion sections, we critically discuss the findings.

\section{Methods}

Comparative methodology aimed at establishing patterns, trends and general principles of image functioning in literary texts written within the same era and one national culture allows considering general patterns of the figurative structure of the novels of Austrian writers of the early twentieth century - Werfel and Canetti. The specifics of the author's thinking are clearly revealed against the background of comparison with the similar.

The comparison is carried out firstly at the level of the types of bestiary images presented in the texts of the novels "Barbara or Piety" and "Blinding", since the very fact of the presence or absence of zoomorphic figures related to a particular element emphasising certain meanings is important. Secondly, bestiary images are considered as an iconic sign: the simplest, based on the similarity of the things involved in the creation of signs of a higher order (index, symbol) (Pearce, 2000, 200-223).

Bestiary medieval culture, the heyday of which goes to the 12th-13th Centuries, is based on the principle of ambiguity and captures the archetypal motives, in which both real and imaginary animals are part of the author's axiology and ontology (Bestiaries and elements, 2013). World - as defined by an ancient poet Alain de Lille- is a mirror into which we look. Becoming signs, animalistic images undergo in literature different kinds of transformation and modification. M.M. Bakhtin in a discourse on Flaubert emphasises that "the specific unity of life" cannot be understood "within the narrow human frame", and "the unconscious center" of the "art world" is "the monument of the animal" (Bakhtin, 1997, 130).
Complication and enrichment of bestiary images with new meanings due to intra-novel associations is one of the most critical problems of the study. The bestiary section of the poetics of two Austrian modernists, equally intense leading research in the field of religion - Werfel and Canetti - is of considerable interest. In the art world of both authors, in their philosophical universe, anthropology is combined with archetypical and symbolic meanings created by the animalistic context.

\section{Results}

The study tells about animals as bestiary images in the novels of Werfel "Barbara, or Piety" and Canetti "Auto da Fé" - from their direct representation to mythological images, to transformation into tools of demonstration of the characters' psychological state, for subsequent transfer to the section of allegories and personifications.

The anthropomorphic gallery of beasts in the novels is directly related to the religious and worldview position of each of the authors. Being interested in the idea of world religion in the 1920s, F. Werfel combines the images of Christian, Greco-Roman and Eastern mythologies in the novel, the main ones of which in the novel are as follows: horses, insects, and birds. Bringing the religious beliefs under his theory of mass, E. Canetti interprets society as a pack, referring to Eastern and Christian mythology as a source of bestiary characters in his novel "Blinding".

Animals are essential to both authors as the embodiment of the idea of sacrifice: they fit into the ritual context, their task is to purify a person, to renew a character. For example, the death of the horse shocks Werfel's young character, who realises that there is active compassion. Canetti draws animals in captivity, which are a symbol of compassion for Buddhists, but, in the main character's opinion, animal trade devalues the essence of custom, shows man's complete indifference to the fate of animals.

Bird images reflect the chaos of the "new reality". In Werfel's novel there is a white rooster 
- Chauntecleer, related to its literary predecessor already at the level of a nickname: a knight from the medieval "Novel about the Fox", associated with revolutionaries in the context of the new era.

Canetti refers to Eastern and Christian mythology, to the plots, which also included birds. For example, for Buddhists, the birds in captivity are a symbol of compassion, which in the mind of the protagonist is reduced to complete indifference of the human to the fate of animal, as captivated birds became trafficked. In the novel "Auto da Fé", Canetti refers to the image of a "white pigeon" in the picture with the Last Supper. As is known, a white pigeon in Christianity embodies the image of the Holy Spirit. In Canetti's novel, a white pigeon's image is undergoing a double transformation, becoming a symbol of the "brainless world". Both writers used the image of a rooster: Werfel - a white rooster, Canetti - a red rooster. Both writers transfer the traditional emblematic plan into complex symbolism which can be read at different levels.

The images demonstrating the idea of synthesis and opposition of the elements appear differently in the novels. The antithesis of a clam and a bird - water and air, dirt and morality are parallel to the opposition of Kien and Theresa in "Blinding". Dragon is a symbiosis of birds and snakes; it embodies the relationship with water, air, and fire in "Barbara", having passed the way of metamorphoses in the character's mind, it is variously associated with heroes who can lead and inspire and with fruitless idealists, whose age has already passed. The following section discusses the results, taxonomically classifying into three categories: Standpoint problem; "Iconic" of an animal; and Heterogeneous image, Index \& Symbol.

\section{Discussion}

\section{Standpoint Problem}

The analysed novels were written almost simultaneously at the turn of the 1920s-1930s, in an atmosphere of political and intellectual tension, when the world seemed "gone crazy".
Writers express a feeling of instability of the world, losing ground and reference points in different ways.

Werfel draws the world that has broken into fragments (chapters of the novel are called "Lebensfragment"). Temporary links are lost: Imperial Vienna is fundamentally not similar to the one that has been plunged into ruin by war and to the post-war capital that was swarming with revolutionary ideas and protest sentiments, and others; as well as the spatial ones - the Magyars, Germans, Ukrainians, and other peoples realise their national identity.

The reader perceives the pictures of the "big history" drawn by the author through the view of the character with Unnahbarkeit (Werfel, $1988,124)$ - a sense of non-closeness, alienation, the ability to take a detached perspective on the most terrible events. Ferdinand's dominant life sensation is an outside observer who maintains his sanity among any disasters, which is facilitated by the form of memories that connects all the narrative layers of the novel, and the position of a staff worker, which is taken by the character - a telephone operator and then an officer. His attention snatches up sharp strokes of cruel pictures, stops at what is insignificant as much as historically significant. Due to Ferdinand's sweeping glance, the scattered strokes of history are strangely combined into a holistic panorama.

In the novel "Auto da Fé", "real" animals are almost absent because they are missing not only in life but also in the mind of the main character - a sinologist Peter Kien, whose sole value is his library. He is not interested in the world around him, he is "a head without world" because his "world is in his head". This is not a simple play on words selected by Elias Canetti as chapter names. The misanthrope Kien is a theorist, who develops his own scale of values, in which there is no place for living - people and animals; all the space is given to thoughts derived from books.

The surrounding world appears to him as a set of grotesque types perceived as the embodiment of a psychic anomaly, interpreting reality in a wrong way and the appearance of a 
psychotherapist at the end of the gallery of these carnival jesters seems a natural outcome.

While Werfel uses fragmentation, assembly, rupture of the time sequence, Canetti refers to grotesque, paradox, breaks the reader's expectations. However, in either case, the character, who feels like an outside observer, better and brighter perceives the essence of the events unfolding before him, associating people with animals, the society with a flock, chicken coop or herd, and sometimes not looking at people, but at animals.

\section{"Iconic" of an Animal}

The study of zoopoetics of texts helps to identify their axiological foundation.

Werfel, having passed a difficult way from Judaism to Catholicism, from Expressionism to its denial, quite often turns to an animal as an object of man's cruelty and affection - the application of his humanity or inhumanity. The "animalistic context" of Canetti (Shastina, 2015) is fairly representative, ranging from "Sketches" ("Aufzeichnungen"), which in different years were published as individual books, to the study "Crowds and Power"("Masse und Macht"). Excerpts from these and other different by genre works of the Austrian writer dedicated to animals are collected in the book "On Animals" ("Über Tiere"), which was published after the author's death (Canetti, 2002).

At the same time, it is obvious that in the texts under consideration, animals as such are represented in a rather focused way in several important but local fragments.

The first encounter with the war of Werfel's character Ferdinand R. is associated with the sight of dying horses, which stable was hit by a shell during the shelling.

The character takes a cursory look at the explosions, the sight of the earth ploughed up with bombs and soldiers' shouts. He begins to look more and more attentively when he realizes that the "majestic (Größe) landscape" with "touching graceful cranes" (Rührend Graziöseres) (Werfel 1988, 197) is destroyed and deformed by the consequences of the explosions he had just heard. Finally, the sight of dying horses makes him finally stop his attention. The character in all its horror does not realise the terrible picture. He captures the elements: weeping eyes, convulsive movement, mane colour.

The visualisation is subordinated to the task of not "verisimilitude", but of ideological emphasis: the iconic integrity of the image is deliberately taken apart. The horror is expressed through micro-details. Fear for one's own life takes a backseat to the animal's pain: "Die Pferde schrien nicht "menschlich", so wie man von leidenden Tieren zu sagen pflegt, sie schrien „pfredlich", aber so, als übersteige die Seelenkraft eines Pferdes jede menchliche Vorstellung an Schmerzensmaß" (Werfel 1988, 198). As a result, the killing of a wounded horse gives rise to an insoluble moral conflict. Realising the rightness of the veterinarian who gave the order to shoot, Ferdinand alternates descriptions of glances of the horse, its killer, and the veterinarian: the eyes of all three become the only subject of description - these eyes express pain, there is no forgiveness, no acceptance of death, no understanding of its necessity in them. There is no humane murder. No justified cruelty. The person who takes this decision is a sinner. The iconic sign acquires metaphysical meanings.

In the novel "Blinding" there are virtually no "real" animals. However, animals and birds appear repeatedly in the characters' stories, in their dreams. So, Kien, who was ready to perform a feat (he will buy out and save books), talks about Buddhist pilgrims' custom to buy out captive animals. Human self-interest hypocritically demonstrates itself in deceitful humanism: "The fattest pig will face an easy natural death, while a noble benefactor will get a reward for his good deeds" (Canetti, 1988, 236). Canetti's character emphasises those characteristics of the image that devalue the victim: "fat", "stupid", "loudly screaming". The sinologist Kien should be well aware of the legend of the Buddha, who is willing to sacrifice himself for the salvation of a dove, but new benefactors make him a skeptic. Canetti 
transforms the idea of human compassion to animals, the new civilisation is already unresponsive to their pleas.

Thus, in both cases, the iconic sign brings the reader close to the idea of sacrifice, which is further aggravated by mythological connotations of the selected animals: a horse in Werfel's novel and a crocodile, a pig, and a turtle -in Canetti's novel. In both cases, an example of human cruelty and indifference is a beast endowed in the mythological coordinate system with the meanings of a psychopomp, a seer and even the world basis. If a victim should purify, enlighten and mark a specific beginning for a person, in the considered novels, it either leads the character along the path of delusion \{Kien believes that if to replace "these ridiculously silly animals with books", the victim will "acquire the highest moral value" (Kanetti, $1988,236)\}$ or reveals to him the terrible truth of the world (Ferdinand realises the empty cruelty of the battle).

\section{Heterogeneous Image, Index, Symbol}

The novel "Barbara, or Piety" (1929) reflects the personality of the character (a ship's doctor Ferdinand R.) in the shadow of historical upheavals. Compositionally, the novel is divided by the author into four "Lebensfragmente": the first two (representing the first compositional part) are associated with childhood in the barracks and military youth, the third and fourth (second compositional part) - with the revolution and the beginning of "new life". For most parameters, these are opposite parts: the world of order gave way to chaos, fatality - to hope, achromatism - to the splashes of bright red colour. The time represented by Werfel is full of "bestien" ("Bestien" (Werfel, 1988, p. 388)): enlightened apostates, embodying "the horror of all the angels", "Lucifer's treason seal" (Werfel, 1988, p. 388). Unconditional "beastliness" \{"Bestialitäten" (Werfel, 1988, p. 406)\} is a characteristic of war. Other aspects of life are characterised through the many-valued complex of motives, images and associations.

The image of the Dragon combines two compositional parts of the novel, as it appears in both of them. In childhood, it embodies for Ferdinand obscure mortal danger, materialised when he sees real asps. The magic story about robbers and cave, told by Franta - Barbara's nephew, babysitter of Ferdinand, is a way out, invented by Ferdinand to build a wall around a fracture in a rock, ends with the advent of a poisonous snake and "battle", in which Ferdinand saves "Drachentöter" (Werfel, 1988, p. 86) of Frant. With the revolutionary times, "the era of the Dragon" comes for the adult character: "The world turned into a Dragon's incarnate, horror, blowing nose, rancor and malevolence ..." (Werfel, 1988, p. 316). "Amber" (Werfel, 1988, p. 336) and green are the colours of the hall, where revolutionaries are gathered, a sense of cave's darkness and humidity of mosses, the view that the hall is the "shadowland" (Werfel, 1988, p. 340), inhabited by "the victims to the slaughter" (Werfel, 1988, p. 339), makes what is happening unreal, alien and distant in the eyes of the character. Dragon, found in "Apocalypse of St. John, the Apostle", is a symbol of Satan, and Ferdinand realises the proximity of his revolutionary friends as temptation.

The Dragon is "a combinatorial image", in most mythologies connecting "upper (birds) and lower (snakes)" worlds; it embodies the "relationship with water", but also with "opposite symbols" air and fire (Ivanov, 1994, 394). If in the mind of Werfel's protagonist, the Dragon is associated with the overall attitude to the time, the dominant sense of fear, uncertainty, the ambiguity of the future, in each specific character, encountered by is Ferdinand $R$. on his formation path, it is refracted with individual features and elements. The total imagery of the novel, in which the motive of death relates to the water element, and life - to air and fire (read more about this in the article: Seibel, Shastina, Volokitina, Ziganshina, 2017), is realised in the image of the Dragon and in the comparison of different groups and types of characters or birds (air element, life) or snakes and insects (water element, death).

Relationship with the elements of air and fire is 
embodied by the characters, who realise their life potential, are capable to "share" their love, guide and inspire others. Such characters are associated with birds and embody the "part" of the overall image of Dragon-world, Dragon-era in its, if not absolutely positive, but viable hypostasis. So, Barbara is "close to God like a bird to heaven": "Barbaras ruhte ahnungslos Seele in der Religion, wie ein Tier des Waldes, ein Vogel der Luft ahnungslos in seinem Element lebt" (Werfel, 1988, p. 28). In direct parallel with the rooster Febuso, whose cage stands in a cubbyhole of revolutionaries, the writer sketches the image of "Russian" Elkan, "hated animal" ("verhasstes Tier" (Werfel, 1988, p. 425)), seeing after his "fleet"-henhouse. The "leader" of feminists Gebhard embodies the strength and equanimity of a feathered hunter: his "noble face of a flesh bird ... is relaxed" (Werfel, 1988, p. 450), "an eagle's head... between the evil brood-hens softly nods and pecks words" (p. 329).

This group of characters is affected by progressive metamorphosis, and any temporary disappointment (as with the Gebhard, with whom Ferdinand was unable to get along) is overcome by the impression of the hidden forces and "something frightening with all clarity" (Werfel, 1988, p. 325). Images can receive bestiary filling not through direct associations with a particular animal, but indirect characteristics. Most often, this is the sounds produced by them ("strange dialect" when Barbara speaks the dialect of her homeland, "strange voices" in the room of Gebhard, "filled with the sound warble" Rabbi, to whom Ferdinand goes with a friend), the verbs of motion (Barbara "shriveled", "ruffled up her fears", "sat and defended his dream", Elkan "carelessly waggled", "kept head down") and oddities in the "habits" (Elkan prefers to "conveniently sit down" on the highest items of furniture: table, stove, etc.).

The other group embodies the part of meanings that unite the world dragon with the water element. It is heroes, suffering defeat, peeved and unrealised. The relationship of water element with death in the aesthetics of Werfel is embodied in their inability to implement a mission, a vocation, even a plan. They become like insects, sliding across the surface of water: Basil "is similar to the thin transparent insect" ("das feine und spinnen gleidrige Insekt" (Werfel, 1988, p. 333)), women in the revolutionary circle are associated with "a fly, trapped in a glass of water" that "kicked" (Werfel, 1988, p. 353). The "detraction" of these characters (Makhov, 2011) is consistently done via the age accent (Basil - an old man who "walked into the climax" (Werfel, 1988, p. 447) in contrast to Barbara, whose permanence despite time - is stressed at each meeting with Ferdinand), nudity (Paulina and Lisa, in the mug of Gebhard), the sounds of their speech ("bubbling", "buzzing"), mimicry and gestures ("trembling", "slips", "causes a poisonous wound"). These characters live with the feeling of defeat and are struggling to play their role in history, understanding the controversy of their situation. They are often vengeful (e.g. Basil, detesting the former mistress for that she has achieved success), petty, almost inhuman (like Lisa, who forgot to give the name to her child). Werfel turns to game with dimensions: intelligent attempts of heroes-insects have been disappointing, undergoing scaling. They are "the poor freaks" (Werfel, 1988, p. 399), as opposed to, for example, Rabbi, who is described as "fabulously frightening" ("märchenhafterschreckend") (Werfel, 1988, p. 401), "giant" (Gigant) (Werfel, 1988, p. 401), "leviathan" (Riese) (Werfel, 1988, p. 402), "Colossus" ("Koloß") (Werfel, 1988, p. 406) and "jumbo" ("Gewaltige") (Werfel, 1988, p. 406). Sometimes they are directly humiliated through comparing with dirt ("shake up shit") (Mist) (Werfel, 1988, p. 391) and depersonalisation ("painful theatre") (Werfel, 1988, p. 395), but more often the hopelessness of their situation is regrettable, as they relate to the outgoing time of the old culture, the shattered tradition, lost value system.

A group of heroes (air and water) are clones of one another in relation to the areas in which they are realised. 
So, Barbara is the embodiment of motherhood without a child. She is the epitome of home, the world of childhood for her pupil Ferdinand, though in the novel, there is a mention of the fact that she lost her own child. She is light and soaring, love and faith, even though "she rarely mentioned God's name, in that there was no need for her" (Werfel, 1988, p. 57). In contrast to her, in the company of the "column hall" appears Lisa - a mother, ignoring the "ribbiting creature" (Werfel, 1988, p. 354), not experiencing maternal feelings, accused by the author of "weakening the animal instinct" (Werfel, 1988, p. 354), unable to take care of someone.

The central image is an irregular meeting of revolutionaries is a white rooster, guarding the cage with the hens, to which nobody "dares to approach" (Werfel, 1988, p. 423). His "counterparts", Gebhard and Elkan, are "grey cardinals" of the revolution: holding in the shadows, they teach speakers, organise the strikes. Not taking tigerism and militancy of "Chantecler, ... the animal from the emblem of the French nation!" (Werfel, 1988, p. 423), they act strategically and seize power over minds and determine the mood of the masses. At the same time, a brilliant publisher of revolutionary magazines, full of pathos and "proudly going towards changes" (Werfel, 1988, p. 444), "skinny and gray" (Werfel, 1988, p. 445) Basil realises that the time has come for his "successors" (Werfel, 1988, p. 445).

Canetti blurs the boundaries between animals and humans; the animal for him is a measure of humanity: "Er denkt in Tieren, wie ein anderer in Begriffen" (he thinks animals as other concepts) (Canetti, 2002, p. 95), moreover, "every animal can be perceived as a potential human being" ("jedes Tier als potentieller ein Mensch an gesehen year worden wäre") (Timmermann, 1985 , p. 114) and conversely, some characters, such as those of the novel "Auto da Fé", would feel much more comfortable in the skin of a wild beast. So, the retired policeman Pfaff, whose speech resembles deadly growl, is called in the novel a "wild beast", "lion in the den", he compares himself with "a red cat", ready to deal with anyone who refuses to obey him. His lifelong dream is to become an owner of the zoo store.

Canetti introduces in his novel a half-man, half ape - a gorilla-like creature that in search of harmony creates his world and his own language. Peter's brother Georges - a lucky doctor-psychiatrist, who arrived from Paris to save his brother from primitive and avid Therese, saw in this creature some resemblance of a mythical unity of intellect and instincts. A "border situation" in the evolution of the human race is shown as if the other way around. This hybrid creature into a greater extent a man, there is the "divine principle" in him, because he settles "his Universe": ... "he moved the whole world into two rooms. He created what he needed. And after six days, on the seventh, understood this. Instead of retiring on his laurels, he gave his creature a language" (Canetti, 1988, p. 431). The man appropriates the traits and characteristics of the beast, and some of them begin to relate to each other in the figurative system of the novel.

A bird and a clam appear as complementary characteristics of Theresa. Kien's primitive and greedy servant, who pretends to moral purity and exceptional morality, resembles a "lump of mucus" (Canetti, 1988, 80), hiding its insignificance behind the dense curtain of standards, rules, prejudices, as they protect it, hide the unviability of this "water creature".

Peter Kien talked about the custom of Buddhist pilgrims to purchase captive animals, not without pleasure, stating that people are indifferent to the destiny of animals: "It is only about the animals. And they can be indifferent" (Canetti, 1988, pp. 235-236).

Kien believes that if to replace "those comically stupid animals with books", this action "becomes the highest moral value" (Canetti, 1988 , p. 236). The sinologist Kien should well know the legend of the Buddha, who is willing to sacrifice himself for the sake of a dove. Canetti transforms the idea of a person's compassion for "fellow creatures", illustrates, in the words of M.M. Bakhtin, the idea that "European humanity 
of new time forgot of the beast problem (as it forgot of many other things), a beast hurts neither conscience nor thoughts of a person" (Bakhtin, 1997, p. 130).

In the logic of the present study, a particular role is played by iconic images of birds. In one of the chapters of the novel, called "Judas and Savior", it is about the painting "The Last Supper", which was seen in the Cathedral by the protagonist's wife, primitive and avid Therese. The famous parable of the meal of Jesus Christ and the twelve apostles, when he predicts the betrayal of Judas, is presented as though vice versa, since the interpretation of Therese, who represents hawkish ignorance, leads to a complete distortion of the biblical story. She deems herself a white pigeon hovering over Judas and Saviour: "Therese stood on her knees in front of the picture. Again and again, she became a white pigeon. She spoke it wholeheartedly and kept an eye on him. She flitted into the hands of the interesting person; he gently stroked her because she constantly rescued him, that is the way it is done to treat pigeons" (Canetti, 1988, p. 150). Kien, identifying himself with Christ, becomes in view of Therese Judas; Therese, who dreams about "an interesting person" thinks of herself as a white pigeon, which is the symbol of the Holy Spirit; Grub, an avid dealer, turns in Therese's eyes into the Savior. An unexpected turn of theme changes the perspective of the narrative: "Behind the cathedral on a stone figure sat a real white pigeon. Therese looked closer: it was Christ, being weary of toothache" (Canetti, 1988, p.150). "A white dove" in the function of an iconic sign "evolves" in the text of the novel, acquires additional meanings, becoming a complex symbol that unites the mythological representations, having experienced all sorts of transformations. As is well known, in the basis of Canetti's system of the perception of the world lies "the myth about transformation" (Mythos von der Verwandlung) (Angelova, 2005, p. 131). For Canetti, metaphorically named by K. Hornik "Mythoman" (Hornik, 2006), it is essential to find "the traces of transformations" in mythology.
The synthesis of water and air, the liberty of subjective "transformations", the arbitrariness of the interpretation of mythology shows hidden inner motifs that become the spring of the image.

The accentuation of different associative and cultural-historical contexts of similar images is obvious in the novels by Werfel and Canetti.

Georges on the eve of the meeting with Peter sees in his dream himself and his brother in the guise of two fighting cocks - "red and weak" and "groomed and cunning" (Canetti, 1988, p. 448). In "sleep script", further developments are described: disputes of the elder brother - the red rooster with the younger brother - the little rooster: "The battle lasted long, it was so interesting that you forgot to think. ... See, one spectator said, what comes from people! From people? The little rooster crowed. - Where are people? We are roosters. Fighting roosters" (Canetti, 1988, pp. 448-449). The principle of subjective inversion - common for Canetti - is also used here. In the final chapter of the novel "The red rooster" ("Der rote Hahn") Kien is burned together with his invaluable library. The red rooster, which for Peter Kien - "the chief Sinologist" of his time, according to the Chinese tradition, should serve as a talisman against fire, in the story becomes a symbol of fire.

\section{Conclusion}

In the novels by Werfel and Canetti there are different types of representation of relations "man-animal": identifying individual traits and characteristics, the antithesis of different elements inside the image, duplicity, association through scenic and musical emphasis, etc. A sign occurs based on physical resemblance and cultural memory related to animals. Bestiary images are demonstrated as mythological and hybrid creatures, when the boundaries between man and animal are erased, which allows drawing a conclusion about a particular anthropomorphic and zoomorphic perception of animals, which is the characteristic of both authors. The research of the works by Werfel and Canetti, given the iconic nature of the bestiary images, seems relevant to detect 
common patterns of development of European literature and culture of the first third of the 20th Century.

\section{References}

Angelova, P. (2005). Elias Canetti. Spuren zum mythischen Denken. Wien: Paul Zsolnay. Addai-Mununkum, R. (2019). Students' representation of "other" religions. Journal Of Curriculum Studies Research, 1(1), 1-16. Retrieved on 01 January 2019 from, https://curriculumstudies.org/index.php/CS/arti cle/view/2

Bakhtin, M.M. (1997). About Floebert. Collected works M.M. Bakhtina. M.: Russian dictionaries, 5, 130-137.

Bartelmus, M. (2015). Kleists Teichoskopie auf die Moderne. Über Kollektive, Meuten, Subjekte und das Tier-Werden im Trauerspiel Penthesilea, Journal of Literary Theory, 9 (2), 161-185.

Bozhkova G.N., Shastina E.M., Kalimullina O.V., \& Shatunova O.V. (2019). Study of literary images of gifted characters in optional activities as a means to develop capable and talented youth, Journal Space and Culture, India, 7(1), 264- 273, https://doi.org/10.20896/saci.v7i1.463 Canetti, E. (1988). Blinding: Roman. Transl. by S. Apta. Moscow, Fiction, 496.

Canetti, E. (1999). Die Blendung. Roman. Frankfurt am Main: Fischer Taschenbuch Verlag. Canetti, E. (2002). Über Tiere. Mit einem Nachwort von Brigitte Kronauer. München/Wien: Carl Hanser Verlag.

Derrida J. (2000). About grammar. M .: Ad Marginem

Deleuze J., \& Guatari F. (2007). The Thousand Surfaces. Blue sofa. Issue 10/11, Moscow, "Three Squares", 7-15.

Donahue, W.C. (2007). The worlds of Elias Canetti: Centenary Essays. Donahue W.C. \& Julian Preece (eds). Newcastle: Cambridge Scholars Publishing, XXVII
Driscoll, K. (2015). The Sticky Temptation of Poetry, Journal of Literary Theory, 9(2), 212229.

Hornik, K. (2006). Myth man and cannibals. Bielefeld: Aisthesis Ivanov, V.V. (1994). Dragon. Myths of the peoples of the world: Encyclopedia. Ed. by S.A. Tolkachev. Moscow: The Russian Encyclopedia, 1, 394-395.

Lvov A.L. (2013). Bestiary and Elements Collection of articles. Moscow: Intrada. Magsumov, T.A. (2019). Gender Re(e)volution of commercial schools in Russia in the early XX century. Woman in Russian Society, 1, 133-144. doi: 10.21064/WinRS.2019.1.12

Makhov, AE (2011). Medieval image. Between theology and rhetoric. Experience interpreting visual demonology. Moscow: Kulagina-Intrada Publishing House.

Mikhaylin, V., \& Reshetnikova, E. (2013).A Little Horse, anthropological notes on the fields of animal studies. Review of foreign books (Electronic resource) UFO. 2013. No. 124. Retrieved on 01 January 2019 from, http://magazines.russ.ru/nlo/2013/124/29m.ht $\mathrm{ml}$

Norris, M. (1985). Beasts of the Modern Imagination: Darwin, Nietzsche, Kafka, Ernst, \& Lawrence, Baltimore: The Johns Hopkins University Press.

Pierce, C.S. (2000). Selected philosophical works. Translated by K. Golubovich, K. Chukhrukidze, T. Dmitrieva. Moscow, Logos. Reiterer, M. (2002). Verzauberung durch Tiere eine Poetologie der Verschiedenartigkeit. Literatur und Kritik. H. 365-366, 86-87. Saenko, N., Voronkova, O., Volk, M., \& Voroshilova, O. (2019). The social responsibility of a scientist: Philosophical aspect of contemporary discussions. Journal of Social Studies Education Research, 10(3), 332-345. Seibel N. E., Shastina E.M., Volokitina N.I., \& Ziganshina N.F. (2017). The Motive of Death in the Austrian Novel of the Late 1920s - Early 1930s. Rupkatha Journal on Interdisciplinary Studies in Humanities, 9(2), 164- 174. 
Shastina, E. (2015). "Animalistic context" of

Elias Canetti. Mediterranean Journal of Social Sciences, 4 (S2), 432-437,

Doi:10.5901/mjss.2015.v6n4s2p432

Timmermann, H. (1985). Tierisches in der Anthropologie und Poetik Elias Canettis.

Höllerer, 99-126.

Vural, H. (2019). The Relationship of Personality

Traits with English Speaking Anxiety. Research in Educational Policy and Management, 1(1), 55-74. Retrieved on 31 December 2019 from, https://repamjournal.org/index.php/REPAM/ar ticle/view/9

Werfel, F. (1988). Barbara oder die

Frömmigkeit. Frankfurt am Main: Fischer Taschenbuch Verl. 